\title{
Migrants on Skis: Norwegian-Latin American Return Migration in the $1890 \mathrm{~s}$
}

\author{
Cecilia Alvstad \\ But I reached the conclusion that the best thing I could do was to get \\ out of South America as soon as possible. ${ }^{1}$
}

\section{Introduction}

On January 18, 1890, about two months after having read a highly unusual job advertisement, twelve young men left Norway for Argentina. ${ }^{2}$ The Chilean railway company Clark \& Co. had employed them to ski with letters and telegrams over the Andes. The top tunnel of the Transandine Railway was under construction, and postal service between the Argentinean and the Chilean sides of La Cordillera was therefore necessary, also during the winter months. The Norwegians were contracted in order to solve this problem. Less than two years later, only one of the Norwegians was still in Latin America; he had married a Chilean woman, and they were expecting their first of four children. ${ }^{3}$ Eight of the twelve Norwegian skiers had returned to Norway, two had continued to the United States, and one was deceased.

The aim of the present book is to shed light on why so few of the Norwegians who went to Latin America from 1820 to 1940 decided to stay. This chapter will exemplify the issue through the decision of the twelve Norwegian skiers to stay, move on, or return. The skiers were employed to do manual work in Argentina right in the middle of this period. Their motivations for leaving Norway, as I will develop further on, seem to have been predominantly economic. Their case presents the typical combination of an adverse condition

1 "Men jeg kom til den slutning at det bedste jeg kunde gjøre var at se og komme mig fra Sydamerika snarest mulig." K.J. Johansen, Norske Skiløbere i Sydamerika. Reiseskildringer (Chicago: John Anderson Publishing, 1892), 129.

2 Ole Hannibal Lie to father, Liverpool, England, January 28, 1890; Johansen, Norske Skiløbere $i$ Sydamerika, 14.

3 Anne Heidi Røstad, e-mail message, November 21, 2013. Røstad is a relative of Gert/Gerardo Lindh and gives this information based on family searches in birth and church registers.

(C) KONINKLIJKE BRILL NV, LEIDEN, 2016 | DOI 10.1163/9789004307391_005

This is an open access chapter distributed under the terms of the Creative Commons Attribution-

Noncommercial 3.0 Unported (CC-BY-NC 3.0) License. 
(economic distress) that pushed them to leave the old country and an attraction (the work contract) that pulled them to the new country, described by for example Loken as typical for Norwegian migration to Canada and the United States. ${ }^{4}$ Nevertheless, when it comes to their decision to stay, move on, or return to Norway, there seem to be two additional sets of factors that influence their decision-making: networks and the conditions at the venue. The network factor relates to the quality of the contacts with other Norwegians they meet, their interaction with other immigrants as well as with the local population. The second factor relates to their material working and living conditions and how historical events may have influenced these. The early 1890 s was a turbulent era in both Argentina and Chile, and the narratives that I will analyze further on tell both about the 1890 civil war in Chile and about political and economic instability in Argentina.

The case of the Norwegian skiers in the Andes is very well documented. Not only has the advertisement for the skiers, published in several Norwegian newspapers such as Verdens Gang, been conserved, so have several related articles published in Aftenposten in $1889-91 .^{5}$ The Norwegian consul general in Buenos Aires either authored or provided information for some of these articles. The skiers themselves also wrote about the event. Theodor Østgaard published five articles in Aftenposten written in Argentina and Chile about the construction of the railway and the experiences of the skiers. ${ }^{6}$ Another of the skiers, K.J. Johansen, who left Norway as Kristen J. Knygg, published the book-length travel account Norske skiløbere i Sydamerika (Norwegian skiers in

4 Gulbrand Loken, From Fjord to Frontier (Toronto: McClelland and Stewart, 1980), 28.

5 The advertisement, entitled "God fortjeneste" (Good earnings), appears in Verdens Gang, November 28, 1889, 4. From what others write it seems to have been published more widely, for example in Aftenposten, but I have not found it there. Related articles are "Skiløbere til Argentinien. En Advarsel," Aftenposten, December 18, 1889, morning edition, 1; "Skiløbere til Argentinien," Aftenposten, December 19, 1889, morning edition, 1; "Norske Skiløbere til Argentina," Aftenposten, January 17, 1890, evening edition, 2; “De norske Skiløbere i Sydamerika. Svar fra den norske Generalkonsul," Aftenposten, August 25, 1891, morning edition, 1; "De norske Skiløbere i Argentina," Aftenposten, October 15, 1891, morning edition, 2. See also note 6.

6 Østgaard's articles were published in Aftenposten on April 10, 1890 (evening edition), May 24, 1890 (evening edition), July 15, 1890 (evening edition), June 2, 1891 (evening edition), and August 16, 1891 (morning edition). Three of the articles are signed T.Ø. (April 10, 1890, July 15, 1890 and June 2, 1891). The article of May 24, 1890, is presented as "from Aftenposten's correspondent in Argentine," and the one of August 16, 1891, is not signed. It is possible that Østgaard wrote more articles. I have found these five searching relevant key words in the digitalized edition available from the national library. 
South America) already in $1892 .{ }^{7}$ A third skier, the farmer Ole Hannibal Lie, wrote a series of letters to family members in Norway. Fourteen of these letters are now part of the HULA database. ${ }^{8}$ A fourth skier, Gert/Gerardo Lindh - who was incidentally the only of the twelve who decided to stay in South America - sent a letter to his sister from Puerto Montt in $1913 .{ }^{9}$ Therefore we know that Lindh was still in Chile twenty years after the events that will be recounted here took place.

The richness of the documents concerning the skiers makes it an interesting case to study. Just like most Norwegian migrants who went to Latin America, the skiers went to Latin America to do manual work. And the material we have about manual workers is generally very scarce. ${ }^{10}$ The material about the skiers however is rich in terms of both authors and genres, making it possible to compare different perspectives. We know that not only the personal point of view influences how individuals describe an event, but that also the textual genre is crucial for what information is presented and how. ${ }^{11}$ In this case we have access

$7 \quad$ Knygg/Johansen had continued to the United States from South America, and the book was therefore published in Chicago by a Norwegian language publisher.

The HULA database entry is available from https://app.uio.no/hf/ilos/hula/korpusliste/. The following letters from Ole Hannibal Lie are registered in HULA:To father, Liverpool, England, January 28, 1890; to father, Mendoza, Argentina, March 4, 189o; to brother, May 26, 189o; to father, Los Cuevas [sic], Argentina, June 8, 189o; to brother, Los Cuevos [sic], Argentina, July 7, 1890; to father, Los Cuevos [sic], Argentina, July 26, 1890; to father, August 1, 189o; to father, Los Cuevas [sic], Argentina, August 13, 1890, this letter must be incorrectly dated because it refers to the content of the next letter as of one already sent; to brother, Los Cuevas [sic], Argentina, August 25, 1890; to father, September 18, 1890; to brother, Mendoza, Argentina, October 21, 189o; to mother, Las Cuevas, Argentina, December 11, 189o; to father, Las Cuevas, Argentina, December 17, 189o; to father, Buenos Ayres [sic], Argentina, March 5, 1890.

This letter has also been preserved, and a transcription was submitted to the HULA database by the sister's great-granddaughter.

See the first chapter of this book for discussion of class composition of Norwegian migration to Latin America and the problem of class bias in primary sources on migration. Similar research show that the educational level of donors of emigrant letters to public repositories in Germany is very high, where more than half of the donors in the study were at least college educated. Wolfgang Helbich and Walter D. Kamphoefner, "How Representative are Emigrant Letters? An Exploration of the German Case," in Letters across Borders: The Epistolary Practices of International Migrants, ed. Bruce S. Elliott et al. (New York: Palgrave Macmillan, 2006), 33.

11 See for example H. Arnold Barton's discussion of the generic differences between letters, diaries, fiction and poetry written by immigrants "As They Tell It Themselves: The Testimony of Immigrant Letters" Nordics in America. The Future of Their Past ed. Odd S. Lovoll (Northfield, Minnesota: The Norwegian-American Historical Association, 1993), $138-45$. 
to letters, a travel account and newpaper articles, genres that typically differ. About the difference between immigrant letters and immigrant fiction Barton, for example, points out that whereas immigrant letters typically express "enthusiasm, satisfaction, a dogged cheerfulness, and optimism in the new land," fictive writers tend to explore the contrary "a sense of loss, alienation and nostalgia."12 In the case of the skiers, the different sources largely confirm each other as regards dates, places, and so forth, but there are also noteworthy differences in what and how they write that I will discuss further on.

The question is then why this is such a well-documented event, even though it concerns workers? One reason may be that the skiers received public attention in Norway already before they left. Clark \& Co.'s advertisement was discussed in the press, and the interest this discussion generated in the general public may in turn have paved the way for Østgaard to write and publish his articles in Aftenposten and for Johansen to write and publish his travel account. From what Lie wrote to his family, the workers also seem to have plenty of free time at their disposal, an essential condition for writing. As pointed out by Barton both practical and psychological circumstances are in play when it comes to who writes and who does not. ${ }^{13}$ The same applies of course for the preservation of the texts.

There has been a long tradition in research to use letters for studying the life of migrants and their motives for leaving their home country and for staying in (or leaving) the new country. As already suggested above it is however not unproblematic to use migrant letters as a historical source, as it is not an easy task to make sense of their meaning. ${ }^{14}$ Immigrant writers were immersed in cultures that informed their tentative writing. ${ }^{15}$ Letters are in other words not the unmediated voice of immigrants. The same difficulties, related to both genre conventions and how the reader is addressed, apply to the other sources as well.

All the migrant voices that are studied here are furthermore directly mediated by others who may have changed what they wrote: decision-makers in Norway have most probably edited Østgaard's original formulations in his Aftenposten articles; an editor presumably helped shape Johansen's book; Lie's and Lindh's letters were handed over to the HULA database by his relatives and were also transcribed by them, and therefore potentially selected, censored and/or mistranscribed. None of the sources can thus be considered to be

\footnotetext{
12 Barton "As They Tell It Themselves," 144.

13 Barton "As They Tell It Themselves," 139.

14 Barton "As They Tell It Themselves," 138-45; Elliott et al., Letters across Borders, 4.

15 Elliott et al., Letters across Borders, 7.
} 
historically reliable as an account of the exact events, nor of what their individual motives for not staying in South America might have been. The access to three important sources mitigates this problem, especially as their narratives largely corroborate each other. Furthermore, the three genres and the three authors enable a deeper reading and thus a better understanding not only of these individuals, but also of the skiers as a group and the Norwegian migration in a larger perspective. We know from earlier research that even husbands and wives can provide diametrically opposite accounts of the "same" situation, and the access to several public accounts is therefore rewarding. ${ }^{16}$ To some extent this may have to do with idiosyncratic differences, but as I will show further on, it has also to do with genre conventions and the internal logic of each narration. Johansen is already early on in his book rather negative towards South Europeans, especially Italians, and it is clear that this negative portrayal prepares the narrative peak of his book, a conflict with the skiers' Italian boss, which leads to Johansen's dismissal and also to him leaving South America.

The story about the Norwegian skiers is also interesting because it is a case that has survived in popular accounts about Norwegians in Latin America, such as Jakob Vaage's Norske ski erobrer verden (1952), Joar Hoel Larsen's Latinamerikanske bilder (1997), and Kjartan Fløgstad's Eld og vatn (1999). ${ }^{17}$ The skiers are also mentioned a couple of times in articles published in Nordmannsforbundet, the journal of an association for Norwegians living abroad. For example, in 1922, more than thirty years after these events took place, Gunnar Nergaard wrote the following in an article about Norwegians in Chile:

On another occasion a group of Norwegians had also been sent to South America. - In order to carry mail and so forth, twelve skiers had been sent to the Transandine Railway, which was under construction. - Nor was this "expedition" particularly successful. - Apparently, only one of them secured a good position and remained in the country. ${ }^{18}$

16 Leo Schelbert, "On Interpreting Immigrant Letters: The Case of Johann Caspar and Wilhelmina Honegger-Hanhart," Yearbook of German-American Studies 17 (Lawrence: University of Kansas Press, 1981), 141-52.

17 Jakob Vaage, Norske ski erobrer verden (Oslo: Gyldendal Norsk Forlag, 1952), 193-99; Joar Hoel Larsen, Latinamerikanske bilder (Oslo: Pax Forlag, 1997), 467-70; Kjartan Fløgstad, Eld og vatn. Nordmenn i Sør-Amerika (Oslo: Universitetsforlaget, 1999), 163.

18 "En anden gang var ogsaa en gruppe nordmænd sendt ut til Syd-Amerika. - Til posttransport etc. blev 12 skiløpere sendt ut til Andesbanen, som var under bygning. - Denne 'ekspedition' blev heller ikke særlig vellykket. - Vistnok bare en opnaade en god stilling og blev i landet." Gunnar Nergaard, “Nordmænd i Chile," Nordmannsforbundet 15 (1922): 307. 
This reference to the Norwegian skiers is not only that they are still part of the narrative about Norwegians in Chile. However, it is also worth noting that they are remembered as a collective without names, and that the anonymity also applies to the one member of the group who stayed. This goes against the general tendency in Nordmannsforbundet which was to write about individual Norwegians and their achievements abroad and there is most probably a link here to the skiers being manual workers, and therefore not the typical Norwegian to be mentioned in the journal Nordmannsforbundet in the first place. ${ }^{19}$

\section{The Twelve Skiers and their Motives for Leaving Norway}

Clark \& Co.'s job advertisement was published with the heading "Good earnings." ${ }^{20}$ Since the men in question responded to this advertisement, they were presumably not indifferent to the possibility of making good money, but they may also have had other motives for leaving Norway for Argentina. In this section I will therefore address the following set of questions: Were the twelve men forced by economic or other circumstances to leave their homeland? Was the choice of Argentina deliberate or arbitrary? Do the men present themselves as voluntary migrants? And if so, were they drawn by the handsome pay, the sense of adventure, or both?

Before looking at the skiers' personal motives and motivations for answering the advertisement, I will address the question of why this advertisement was published in Norway in the first place. The extant sources do not provide any clear answers, but two circumstances ought to be noticed. First, we know that Norwegian engineers were already working in the Andes on the construction of the Transandine Railway. It is therefore likely that the idea about hiring Norwegian workers as skiers originated in relation to them. ${ }^{21}$ Secondly, as I will comment further on, it is clear that the Norwegian consul general in Buenos Aires was involved already at an early stage: after the advertisement was

19 See, for example, Gunnar Nergaard, "Nordmænd i Chile," 306-308. Nergaard also briefly mentions the unlucky venture with the Norwegian skiers in an article written ten years later: Gunnar Nergaard, “Over Andesfjellene," Nordmannsforbundet 25 (1932): 10-12.

20 "God fortjeneste," Verdens Gang, November 28, 1889, 4.

21 Vaage, Norske ski erobrer verden, 198, claims that it is "beyond doubt" ("hevet over enhver tvil") that it was the Norwegian consul general in Chile at that time, Rosenqvist, and the Norwegian engineers that made Clark \& Co. advertise for Norwegian skiers. 
published, he defended Clark \& Co.'s reliability in an article in Aftenposten, ${ }^{22}$ and he also met personally with some of the skiers when they passed through Buenos Aires on their way to the Andes. ${ }^{23}$ The reason that these migrants went to Argentina was therefore not because of personal relationships, but because of unrelated Norwegians who were already in Argentina.

The job advertisement in Verdens Gang specified that the company Clark \& Co. was searching for fit and strong men to help construct the railway between Buenos Aires and Valparaíso, in South America. The candidates were to be between twenty-five and thirty-five years old and good skiers, and knowledge on how to preserve fish and meat with salt would furthermore count in their favor. Not only the heading, "Good earnings," but the rest of the advertisement emphasized the financial aspect. The trip was to be paid for, and the skiers were to be paid a good salary: "The monthly salary varies from 150 to 180 kroner. The position includes free travel per steam ship, including meals, from Christiania to the point of destination." ${ }^{24}$

Since no training was required, this must have appeared to be a good opportunity for young men, especially for those who did not have an education or the means to pay for a transatlantic ticket. At the same time, this work might of course be too good to be true. On December 18, 1889, Aftenposten published a warning, signed anonymously by a Norwegian who claimed to know the Andes and the railroad under construction well. ${ }^{25} \mathrm{He}$ declared that the work would be very dangerous and the salary far too low, and also suggested that the sum of 150-180 Norwegian kroner probably meant 150-180 Argentinean pesos, and that the correct equivalent would be only $60-70$ Norwegian kroner, which was very little in Argentina. ${ }^{26}$ The following day saw a response in Aftenposten from the Norwegian consul general in Buenos Aires, who declared that Clark \& Co. had sought their assistance in contracting fifteen Norwegian men who could transport mail by ski. The response highlights the importance of the Transandine Railway and of Clark \& Co.'s standing as a solid, responsible firm that would look after the potential emigrants. ${ }^{27}$

\footnotetext{
22 "Skiløbere til Argentinien," Aftenposten, December 19, 1889, morning edition, 1.

23 Ole Hannibal Lie to father, Mendoza, Argentina, March 4, 1890; Theodor Østgaard, "Hos Mr Clarc \& Co. og Generalkonsul Christophersen," Aftenposten, April 10, 189o, evening edition, 2; Johansen, Norske Skiløbere i Sydamerika, 39-40.

"Lønnen per Maaned varierer fra 150-180 Kroner og faaes fri Reise per Dampskib inclusive Kost fra Christiania til Bestemmelsestedet." "God fortjeneste," Verdens Gang, November 28, 1889, 4 .

"Skiløbere til Argentinien. En advarsel," Aftenposten, December 18, 1889, morning edition, 1. "Skiløbere til Argentinien. En advarsel," Aftenposten, December 18, 1889, morning edition, 1.

27 “Skiløbere til Argentinien," Aftenposten, December 19, 1889, morning edition, 1.
} 
The interest in the advertisement seems to have been immense, and the warning and subsequent response probably increased it. According to Johansen, over two hundred men applied for the position. ${ }^{28}$ His account is nevertheless slightly contradictory here, because in spite of what he writes, Johansen himself was accepted as a reserve although he applied far too late. Also, only twelve men left, but the advertisement was for fifteen. Johansen mentions the warning and that there were different views about whether this was a good opportunity.

Also the skiers' departure received attention in the Norwegian press at the time. On January 17, 1890, Aftenposten published a short article, entitled "Norske Skiløbere til Argentina" (Norwegian skiers to Argentina), about the departure of the skiers. All the names of the skiers were stated in the article, together with their age, place of residence, and (for some of them) occupation. Most of them had worked in Stockholm as part of His Majesty The King's Guard and they were therefore already migrants in Scandinavia. ${ }^{29}$ The union between Norway and Sweden lasted from 1814 to 1905 , and there had been Norwegian royal guards in Stockholm since 1856. In 1888, towards the end of the union with Sweden, the Norwegian guard was transferred from Stockholm to Kristiania (present-day Oslo). ${ }^{30}$ It seems that the changes related to the transfer of the main guard to Kristiania may have forced some of the guards to look for new job openings.

The twelve skiers were also registered in the emigration protocols. ${ }^{31}$ Their names, ages, places of residence, and occupations are stated, and they are registered as leaving Kristiania on the ship Rollo. The information here is more or less identical to that given in Aftenposten, but there are some minor differences. It can therefore be assumed that Aftenposten's source was not the emigration register, so that the two sources corroborate each other.

The information in the emigration protocols provides a good idea about the skiers, none of whom seemed to have higher education: ${ }^{32}$

28 Johansen, Norske Skiløbere i Sydamerika, 10.

29 "Norske Skiløbere til Argentina," Aftenposten, January 17, 189o, evening edition, 2.

30 "His Majesty The King's Guard," last modified November 11, 2013, http://www.kongehuset .no/artikkel.html?tid=29281\&sek=28607.

31 "Emigrantar frå Kristiania 1867-1927 tillegg," Digitalarkivet, Riksantikvaren, accessed April 23, 2014, http://gda.arkivverket.no/cgi-win/webcens.exe?slag=visbase\&sidenr=8\&fil namn $=$ emo3011867tillegg\&gardpostnr $=24748 \&$ personpostnr $=24748 \% 20-\% 20 n e d r e$. The twelve skiers are listed with identification numbers from 24742 to 24753 .

“Emigrantar frå Kristiania 1867-1927 tillegg." 
- Johannes L. Haug (25), Gert Lindh (25), Kristoffer Berg (27), and Ove Løvvik (30), former constables from Kristiania

- Nikolay Sund (26), former constable from Sund in Nordland

- Adolf Mosheim (26), office clerk from Brønnø

- Kristen J. Knygg (26), worker from Brønnø [later named Kristen Johansen]

- Theodor Østgaard (24), errand boy from Kristiania

- Johannes M. Helland (22), shoemaker from Bergen

- Hans Dags Berge (23), sailor from Bergen

- Hans Fougner (29), merchant from Ringebu

- Ole H. Lie (32), farmer from Søndre Land

The emigration protocols furthermore specify the name of the agent, Fredrik Lie, and that the cost of each ticket was 220 kroner. Two of the skiers, Fougner and Lie, carried money with them: Fougner forty kroner and Lie three hundred kroner. This means that ten of the skiers left Norway without any financial means.

Also Johansen's travel account confirms the identity of the skiers, although he only gives the first and last letter of the skiers' surnames. The information he provides about ages and occupations is not completely identical to the other two sources. Østgaard is not referred to as an errand boy, but as a "washedup student" and a "skier without skis." ${ }^{33}$ Berge, the sailor from Bergen, is according to Johansen only nineteen years old (rather than twenty-three); ${ }^{34}$ it is possible Berge lied to the agent about his age to get the position. The sources also disagree slightly on his name: whereas he emigrates as Hans Dags Berge, Aftenposten later uses the name Hans Dagsen Berg. ${ }^{35}$ Johansen calls him "D...n." Lie did not mention the name of this particular person in his letters, but as he mentions most of them at some point, his letters serve in general to corroborate the information given in the other sources.

Judging by the professional profile of the skiers, personal finances may very well have played an important role in their decision to leave. Five of the skiers are listed as "former constables," which implies that they were presently unemployed and that they had been part of the Norwegian guard. That personal finances did play a role is further suggested by what Johansen and to a certain extent Lie write about their own personal circumstances. Kristen Johansen came from a poor family in Hålogaland in Northern Norway. His mother had died when he was seven, and he had to leave home to work when he was nine;

33 “...afdanket Student, Skiløber uden Ski." Johansen, Norske Skiløbere i Sydamerika, 17.

34 Johansen, Norske Skiløbere i Sydamerika, 66.

35 "De norske Skiløbere i Argentina," Aftenposten, October 15, 1891, morning edition, 2. 
he became an orphan at an early age. ${ }^{36}$ Johansen was not married and had been four years in Stockholm as part of His Majesty The King's Guard. He claims to have left the guard when he realized that he would not have a future there. He describes the autumn of 1889 as a very hard time, saying it was "an experience I wouldn't wish upon my worst enemy, if I had any."37 He could not find work, was often hungry, and considered ending his own life. When he was given the opportunity to be one of the skiers, however, he had just been hired by the fire brigade, so leaving was in the end not his only chance to lead a reasonably good life. ${ }^{38}$

Johansen writes that there was much talk about the skiers in Kristiania and that some people advised in favor of going, and others against:

However, there was indeed quite some talk about the town about the skiers bound for Argentina. The various papers wrote about them, some advising them to go, others advising them not to - all in all, it seemed like quite an escapade, but that was what I found so appealing, along with the good pay. ${ }^{39}$

The motives he states for leaving Norway are thus both related to adventure and to his financial situation. Or as he himself sums it up some pages further on, "Wanderlust and the social conditions at the time compelled me to leave."40

Ole Hannibal Lie, in his nine letters to his father, four to his brothers, and one to his mother, does not directly address his motives for leaving. Since the letters are addressed to members of his intimate family, the targeted readers would presumably already be acquainted with his reasons for leaving. A book about the farms of his native region provides more information than he himself does. ${ }^{41}$ Ole Hannibal Lie had been the owner of a farm called Øystad since 1886, a farm that his father, Otto Lie, had bought in 1871 . Since 1872 Otto Lie had also been the owner of a farm called By, which he had inherited from his father;

$3^{6}$ Johansen, Norske Skiløbere i Sydamerika, 19-20.

37 “...en tid, jeg ikke vilde ønske min verste fiende, om jeg havde nogen.” Johansen, Norske Skiløbere i Sydamerika, 7 .

38 Johansen, Norske Skiløbere i Sydamerika, 3-10.

39 "Imidlertid var der ikke saa lidt Snak i Byen om disse Skiløberne til Argentina. De forskjellige Aviser skrev om dem, nogle raadede til, andre fra - alt i alt - det saa adskillig eventyrligt ud, men netop det og at det var god Betaling, var det som trak mig." Johansen, Norske Skiløbere i Sydamerika, 10.

"Reisetrang og samfunnsforhold havde drevet mig ud." Johansen, Norske Skiløbere i Sydamerika, 20.

41 C.S. Schilbred, Gårdshistorie for Søndre Land (Oslo: Cammermeyer, 1962), 24. 
this explains why Ole Hannibal Lie (for the sum of 32,6oo kroner) took over Øystad long before his parents died.

Ole Hannibal Lie had been married to Ellen Marie Hornslien since 1880, but she died on New Year's Eve in 1887 , that is, about two years before he left for Argentina. They had four daughters born between 1882 and 1887. A few references are made to these girls in the letters, and the oldest of them is also mentioned by her name, Maren. The farm Øystad was passed on to the four daughters in 1889 for the sum of 30,200 kroner. $^{42}$

To an outsider who reads his letters, Lie first appears to be a voluntary migrant who enjoys his spell in the new country. There are many descriptions of the impressive landscape, and he also mentions the good, inexpensive horses and the hunting possibilities. A good example of his positive tone is when he writes to his father on March 4, 1890, shortly after his arrival to Argentina: "By the way, I really like it here. My [Norwegian] friends are all good guys, and we have developed a deep bond of friendship."43

In other letters Lie writes about the adventurous aspect of his work:

A tollhouse will now be built here on the mountain. The five of us stationed here were selected to serve as mounted toll officers quite some time ago. It certainly won't be risk-free, but there will of course be many interesting adventures. ${ }^{44}$

From these formulations it would not be far-fetched for an outsider to believe that Lie was there only because he himself had chosen to be there. However, there are also some dark undertones in his letters, and these are difficult to interpret for a reader not familiar with his situation. He thanks his parents for taking care of the small girls, sends them his regards, and also asks his father for forgiveness for being a bad son who has caused him so many troubles; in

42 Schilbred, Gårdshistorie for Søndre Land, 24 and 244-45. There are photos of the two farms Øystad and By on pages 15 and 240.

43 "Jeg liker mig forresten ualmindelig godt. Kammeraterne er alle kjække Karer, og et rørende venskapsforhold er opstaaet mellem os." Ole Hannibal Lie to father, Mendoza, Argentina, March 4, 1890.

44 "Det skal nu oprettes en Toldstation her paa Fjeldet, til ridende Toldopsyn er forlængst udtaget vi 5 som er her, det vil jo ikke blive ganske farefrit, men der vil jo blive mange interessante Eventyr." Ole Hannibal Lie to father, June 8, 1890. A similar formulation can be found in a letter sent to his brother a couple of weeks earlier: "As you can see, there is no lack of adventures here, and they can be fairly interesting once they are finally over" ("Som du ser er her ikke vondt for Eventyr, og de kan jo være noksaa interessante naar de vel er over”). Ole Hannibal Lie to brother, May 26, 1890. 
another letter, he asks his brother about the last auction at Øystad. ${ }^{45}$ Lie frequently discusses what he earns, as well as the economic pros and cons of breaking his contract, and also what he could earn elsewhere, for example in Panama. At the same time he asks his brother twice to make sure that his dog Lona has puppies before getting too old, which indicates that he is planning to come back, but not very soon. ${ }^{46}$

In many ways Lie seems to differ from the other skiers. According to both himself and Johansen, the engineers appointed him as the leader of the group when they arrived in Las Cuevas, and although he does not seem to have higher education, he had another class background than the others. The two family farms are important farms, and he himself was the oldest son. His father had an education in law, and his grandfather was a military captain. ${ }^{47}$ According to the emigrant protocols, Lie was furthermore one of the two who carried money with him, and he had considerably more than Fougner. In other words, although we do not know exactly why he left Norway, his motives seem to be rather complex, probably more so than those of the others. Whereas most of the skiers returned to Norway, both Johansen and Lie continued to the United States, which perhaps suggests that they were the most motivated migrants of the group, whether for financial reasons, the sense of adventure, or other reasons.

\section{The Journey and Arrival to Argentina}

Theodor Østgaard, Kristen Johansen, and Ole Hannibal Lie all write about the journey and the arrival to Argentina. They travelled from Kristiania to Hull on the steamship Rollo; the weather was rough, and when they arrived in Hull, a certain Mr Lazarus, who spoke Norwegian, helped them to a boarding house. The day after, they took the train to Liverpool, where they spent a few days before continuing on the Rosse for Montevideo. The Rosse stopped at St. Vincent before arriving at Montevideo, from where a pilot took them to Ensenada in the province of Buenos Aires. From Ensenada, they continued by train to Buenos Aires, where they met Mr Clark himself; some of them also met with Mr Christophersen, the Norwegian consul general. Finally, the company completed its long journey by taking the train to the city of Mendoza among the eastern foothills of the Andes, where Clark \& Co. had its regional office.

45 Ole Hannibal Lie to brother, August 25, 1890.

46 Ole Hannibal Lie to brother, May 26, 189o, and August 25, 1890.

47 Schilbred, Gårdshistorie for Søndre Land, 244-45. 
Even though Østgaard, Johansen, and Lie do not tell exactly the same story about these events, their narratives generally coincide. This also applies to many of the details. For example, the three of them all relate that they were told to drink wine instead of water. In Østgaard's phrasing: "A bottle of fine wine is served for dinner and evening supper here; we have been instructed to drink as little water as possible now in the beginning. The climate here demands this." ${ }^{48}$

They also provide a similar idea of how difficult it is for them to understand others and to make themselves understood. Lie even recounts that on the train from Buenos Aires to Mendoza, the group only managed to communicate that they were hungry when one of them pointed at his belly and made gestures. But their language problems started already in England, with Johansen and Lie telling of such difficulties in both Hull and Liverpool. All three sources mention that Østgaard was the only one with some knowledge of English. Lie and Johansen write that they spent some time studying Spanish on the Rosse, and Lie later writes that he continues to study Spanish after the group's arrival.

Notably, the three writers differ in how they present and emphasize this information, and these differences are important for the internal logic of their respective narratives. The differences between what Johansen and Lie write about the same events (or the same day or week) are the most striking ones. Whereas Johansen in his book tends to focus on hardships, Lie in his letters writes about pleasures and leisure. A telling example is what they write about their stay in Hull: in Johansen's account, the bed bugs at the local hostel cause all of them to leave the clothes they were wearing behind, but this episode is not mentioned in Lie's letters.

Østgaard, who writes for Aftenposten, naturally has more of the tone of a reporter, as in the following quote:

The second day we were in Buenos Aires, some of us enjoyed a conversation with the Norwegian consul general, Mr Christophersen. The consul said he believed our stay here would be highly advantageous to us. Our wages, £1o per month, were very good, given the current state of affairs in Argentina. For half of what we are to be paid, Clark \& Co. could have found enough men to carry out the same services that we are to perform.

48 "Til Middag og Aften serveres her 1 Flaske god Vin; man har paalagt os i Begynnelsen at drikke saa lidet Vand som muligt. Klimaet her fordrer det." Østgaard, "Hos Mr Clarc \& Co. og Generalkonsul Christophersen," 2. Also in Johansen, Norske Skiløbere i Sydamerika, 47, 140; Lie mentions the wine in various letters, for example to father, Mendoza, Argentina, March 4, 189o, and to brother, May 26, 1890. 
However, the company needed a few outstanding and temperate men, so they had made enquiries in Norway. But it was also demanded of us that we were used to skiing. 49

In other articles Østgaard provides data about the railway and the construction of the tunnel. He depicts the Norwegian skiers very favorably as strong and heroic men who, for instance, impress the locals with their ability to pass the Andes in the snow: "The natives are poor at traversing the snow. The Norwegians' skis have therefore amazed the natives." ${ }^{\text {50 }}$

Østgaard's accounts of the locals are considerably less glowing. Argentineans are described almost as barbarians. One example of this is when he describes how the natives slaughter animals. As in the previous example, Østgaard here establishes a clear difference between Norwegians and South Americans: "Something I believe I should mention in particular for Norwegian readers is the technique of butchery used here. ${ }^{.11} \mathrm{He}$ then describes how two men would ride after the animal, catch it with a lasso after it had become exhausted, and then kill it with a knife by cutting open the abdomen and going for the heart, which differed significantly from the Norwegian procedure. Østgaard concludes that "the entire process is brutal and disgusting." 52 The article ends with a supercilious and generalizing statement about the South American republics: "Even with their freedom and their rich resources, the republics of South America are at a much lower level of genuine civilization." 53

49 "Med den norske Generalkonsul, Hr. Christophersen, havde nogle af us en Samtale den anden Dag, vi var i Buenos Aires. Konsulen mente, vi vilde faa megen Fordel af Opholdet her. Vor Gage, $10 £$ maanedlig, var efter de nuværerende Forhold i Argentina, meget god. Clark \& Co. kunde faa fuldt op af Folk til samme Tjeneste, som den vi skal gjøre, for Halvparten af den Gage, vi skal have. Sagen var, at Kompagniet havde brug for endel udsøgte og ædruelige Mænd. Derfor havde de henvendt sig til Norge. Men vi maatte ogsaa være vante til at bruge Ski." Østgaard, "Hos Mr Clarc \& Co. og Generalkonsul Christophersen," 2.

$5^{0}$ "De indfødte er daarlige til at komme frem i Sneen. De norskes Ski har saaledes vagt de Indfødtes forbauselse." Theodor Østgaard, "Ferro Carril Trasandino," Aftenposten, May 24, 189o, evening edition, 1.

$5^{1} \quad$ "En ting finder jeg specielt at burde omtale for norske Læsere, og det er den Maade, man her slagter paa." Østgaard, "Ferro Carril Trasandino," 1.

52 "Den hele Fremgangsmaade er baade raa og modbydelig." Østgaard, "Ferro Carril Trasandino," 1.

53 "Selv med sin Frihed og sine rige Hjelpekilder staar Syd-Amerikas Republiker meget langt tilbage i sand Civilitation." Østgaard, "Ferro Carril Trasandino," 1. 
Also Johansen is from the start very negative about both Argentina and Argentineans, and he frequently emphasizes how dirty everything is. The first place he describes is Ensenada, and the account he provides is everything but positive and respectful:

The streets - which incidentally do not at all deserve to be referred to as such - were strewn with dead dogs, cats, the entrails of dead animals, trash, and all sorts of nasty things rotting away under the scorching heat of the sun. ${ }^{54}$

The way he depicts the inhabitants of Ensenada, the first South Americans he meets, is no more positive, as they are described as "lazy pigs that only need fruit, meat, and wine to live and can't be bothered with procuring more than they need themselves." 55

His first description of Las Cuevas also emphasizes the dirtiness of the place and its inhabitants:

Thereafter we were shown to a talus with a zinc roof above it to live together with four or five dirty natives. ...Horse feed, human food, pots and pans, cups, riding equipment, dogs, Indians, and Europeans all lay helter-skelter in motley confusion - dirty outside, dirty inside, dirty at the top, dirty on the bottom - dirty people and dirty surroundings. ${ }^{56}$

From the start, Johansen describes the skiers' work as hard. Their first task was to carry stones to build the house they were to live in: "I believe we were all happy when the working day was over, and many seemed to dread the upcoming days. It certainly was a harsh form of work." 57

54 "I Gaderne, der forresten aldeles ikke fortjener saadant Navn, laa døde Hunde, Katte, Indvolde av døde Kreaturer, Søppel og alslags Uhumskheder og raadnede i den brændende Solhede." Johansen, Norske Skiløbere i Sydamerika, 35.

55 “...dovne Grise, der kun trænger Frugt, Kjød og Vin for at leve og ikke gider tilveiebringe mer, end de selv trænger." Johansen, Norske Skiløbere i Sydamerika, 34.

$5^{6}$ "Derpaa blev vi anvist en Stenrøs med Zinktag over til at bo i sammen med en 4-5 skidne indfødte. ....Hestemad, Folkemad, Gryder, Kopper og Kar, Ridegreier, Hunde, Indianere og Europæere laa om hverandre i broget Forvirring - skident ude, skident inde, skident oppe, skident nede - skidne Mennesker og skident rundt om." Johansen, Norske Skiløbere $i$ Sydamerika, 68-69.

57 "Jeg tror, vi alle var glade, da Arbeidstiden var til ende og mange imødesaa vist de kommende Dage med Gru. Det var sandelig strengt Arbeide." Johansen, Norske Skiløbere $i$ Sydamerika, 70 . 
Lie, especially in his early letters, is much more positive to Argentina than Johansen. He writes more about beautiful places and does not depict places or people as dirty. Mendoza, for instance, was "the most wonderful place I have ever been, with its wonderful air and magnificent parks and trees - it is midsummer here, so it is of course the best time of year." ${ }^{58}$ In a letter to his brother dated May 26, 1890, Lie writes that

Valparaiso is a beautiful town, the most gorgeous I have seen, completely European. It extends about five kilometers in the shape of a horseshoe upward toward the mountain, with many wonderful parks with fountains and music the whole day through. ${ }^{59}$

Lie does not describe the work as especially hard. Instead he highlights the adventurous aspects of their life, the riding and the skiing, and their abundance of free time, which he partly used at the time to improve his Spanish. He writes frequently about how easy their life is and that they are having a good time and making good money at the same time. ${ }^{60}$ Lie even encourages his relatives back home and in the United States to come to Argentina. He writes that if his brother wants to come, he will find work, and he also asks his father to convince Aksel (a relative who is unemployed in the United States) to come to Argentina, precisely because he will be able to find work there. ${ }^{61}$ However, as time passes and conditions worsen, Lie warns others and tells them not to come. He even tells about life-threatening situations he has been in, albeit in an entertaining way, which makes it sound almost like fiction.

The differences between Johansen's and Lie's depictions of their first months are striking. Whereas Johansen is very negative about his initial experiences in Argentina and highlights their work as extremely hard and dangerous, Lie paints a completely different picture. He seems to be having a good time with lots of time for hunting, studying, and excursions. It may very well be that their conditions differed considerably: unlike Johansen, Lie had been designated as the head of the group. They may also have slept in different houses (Johansen

58 “...det deiligste Sted jeg nogensinde har været, deilig Luft, præktige Parker og Træplantninger, der er jo her Midtsommer saa det jo er den bedste Tid." Ole Hannibal Lie to father, Mendoza, Argentina, March 4, 1890.

59 "Valparaiso er en nydelig By, den smukkeste jeg har seet, fuldstændig Europæisk. Den strækker sig ca $1 / 2$ mil i Hesteskoform opover mot Fjeldet, i en masse deilige Parker med Springvand og Musik hele Dagen." Ole Hannibal Lie to brother, May 26, 1890.

6o For example in letter to brother, Los Cuevas, Argentina, July 7, 1890.

61 Ole Hannibal Lie to father, June 8, 1890, and to brother, July 7, 1890. 
writes that there was room for some of the skiers in the engineers' house but that he himself did not stay there). It may also be that they perceived the same situations in different ways, that is, that Johansen suffered from the bugs and squalor more than Lie did.

However, the differences may also be related to genre and intended readership. On the one hand, Johansen, who published his book some time after these events took place, may have added a more negative filter afterwards. This would serve a purpose in the context of the book as a whole, since the negative experiences of the first months contributes to the narrative logic of the book. On the other hand, Lie may also have had good reasons for choosing to recount the good experiences rather than the bad ones. For example, he may not have wanted to worry his family, or if they had advised him against going, he may not have wished to prove them right. Also, Lie's letters were dispatched after he wrote them, so he could not go back and retroactively alter his first impressions.

A letter from July 26,1890 , marks a turning point in Lie's narration. In this letter he describes recent uprisings in nearby Chile, also communicating that the company has problems and that it is not a good idea for others to come:

The reason I am writing you now is to tell you a little about the conditions here. The situation is as dire as it could probably be. In Chile - we live two kilometers from the border - there is a total revolt because of the presidential election. Last week ten thousand soldiers marched into Valparaiso, there is warfare everywhere in the country, the railroad has stopped, everything is in a state of siege, and many rebels are shot down every day. It is said that this will also spread to Argentina - there is also an upcoming presidential election here, so yes, there will be bedlam here. If you haven't yet written Aksel, then do so - I wouldn't advise anyone to come here as things currently stand. The situation is also as tough as possible here on the railroad. Rosenquist [a Norwegian engineer] has been fired, though we don't know why. ${ }^{62}$

62 "Hvorfor jeg egentlig skriver nu er for at fortælle dig lidt om Forholdene. De er saa kritiske som vel muligt. I Chile, vi bor 2 km. fra Grændsen, er de fuldstændig Oprør i Anledning Præsidentvalget, i forrige Uge marchered 10.000 Soldater ind i Valparaiso, fuldstændig Krig over hele Landet, Jernbaerne ere standsed, alt er i Beleiringstilstand, en Masse Oprørere bliver nedskudte hver Dag. Der siges at dette ogsaa skal smitte paa Argentina, her er ogsaa forestaaende Præsidentvalg, ja da skal det bli Leven her, Har du ikke skrevet til Aksel, saa gjør det, jeg vill ikke raade nogen til at reise hid, slik som det nu er. Her paa Linien er ogsaa Forholdene saa vrange som muligt. Rosenquist har faaet Avskjed, Grunden hvorfor ved ikke vi." Ole Hannibal Lie to father, Los Cuevos, Argentina, July 26, 1890. 
In his next letter Lie describes the new engineer, an Italian who has replaced Rosenquist, the Norwegian engineer who had been there since they arrived. Lie says that things have now changed for worse in Las Cuevas: there is not much of either work or food, and on top of this they do not get paid. He also writes that some of the Norwegians are discussing the possibility of breaking their contract and going elsewhere, possibly Panama. ${ }^{63}$ But in a later letter, dated August 25, 1890, he writes to his brother that everything is "excellent as always." ${ }^{4}$

\section{Weak Norwegian Networks}

In his book, Johansen opens the chapter about their arrival to South America by telling how dear the sight of no less than ten Norwegian flags among the ships in the harbor of Montevideo was to them as expatriates: "How these dear colors of the flag speak poignantly to the most profound and noble parts of oneself, especially when one is out and about in the world!"65 Johansen, Lie, and Østgaard all write very positively about Norway and the Norwegians they meet. They clearly feel associated to other Norwegians, to other Scandinavians, and to some degree also to Germans. There is only one exception to this in their narratives: when they first arrive to Argentina, Johansen describes a meeting with an assumptive Norwegian in Ensenada, who almost did not condescend to speak to them in Norwegian, even though he was paid by the company to take care of their travel arrangements. ${ }^{66}$

Generally, however, all the authors write very positively about other Scandinavians. This is especially clear in what Johansen writes about the time after his dismissal from Clark \& Co. He then traveled to Chile and Peru and from there to the United States, before staying with a Swede in Valparaíso ${ }^{67}$ and in Callao with a Captain Jensen from Bergen, "who without knowing me bade me reside as a guest with him and his family for the duration of my stay in Callao. ...I was given my own, comfortable room and enjoyed Norwegian

63 Ole Hannibal Lie to father, Los Cuevos, Argentina, July 26, 1890.

64 “...som sædvanlig ualmindelig godt." Ole Hannibal Lie to brother, Los Cuevas, Argentina, August 25, 1890 .

65 "Hvor disse kjære Flagfarver taler et dybtfølt Sprog til det dybeste og ædleste i en - naar man er ude i Verden isærdeleshed." Johansen, Norske Skiløbere i Sydamerika, 33.

66 Johansen, Norske Skiløbere i Sydamerika, 34.

67 Johansen, Norske Skiløbere i Sydamerika, 147. 
food, Norwegian conversation, and true Norwegian hospitality." ${ }^{\prime 68}$ On the ship to the United States he was lucky enough to meet another Norwegian who gave him extra food in exchange for a sum of money. ${ }^{69}$ These references to other Norwegians in Johansen's book demonstrate solidarity between Norwegians (and other Scandinavians). Implicitly, however, these references also indicate that there did not exist any strong Norwegian networks that could help Norwegians to reestablish themselves in South America when they got in trouble. ${ }^{70}$

There also seems to be strong bounds between the skiers, and they are quite direct in what they write about each other. Johansen writes that Lie is a drinker, while Lie for his part writes that Østgaard is a drinker. ${ }^{71}$ Lie furthermore subtly indicates that Østgaard at one point is hospitalized because of a venereal disease; ${ }^{72}$ Johansen is more delicate and does not give away the reason for Østgaard's hospitalization. ${ }^{73}$ To a certain extent these differences may not only have to do with their opinions about one another, but also with the intended readership. Johansen and Østgaard both seem keen to produce an image of the Norwegian skiers as strong and impeccable men who sometimes have a drink or two, but who hardly ever transgress the limits of good behavior, whereas Lie seems to be invested in the image he produces of himself.

When it comes to how Lie and Johansen write about the Norwegian engineers, there is a similar divider between the two. Whereas Lie stresses that he spends time with them, plays cards, and so forth, Johansen writes about the card playing with the engineers as something that happens exceptionally.

68 “...der uden at kjende mig, bød mig tage tiltakke hos ham og hans Familie som gæst den Tid jeg maatte standse i Callao. ...Jeg fikk eget hyggeligt Værelse norsk Mad, norsk Sprog og nød ægte Norsk Gjæstfrihed." Johansen, Norske Skiløbere i Sydamerika, 150.

69 Johansen, Norske Skiløbere i Sydamerika, 152.

70 See Thomas Faist, "Transnationalization in international migration: implications for the study of citizenship and culture," Ethnic and Racial Studies, 23:2 (2000), 189-222. According to Faist, "transnational social spaces and the other names we have given these phenomena are characterized by a high density of interstitial ties on informal or formal, that is to say, institutional levels" (190). Such dense ties do not seem to exist in the spaces described in the documents about the skiers. There is an undeniable collective "we-feeling" (Faist, 193), but the ties are not dense enough to classify within any of the three types of migratory networks identified by Faist, namely "transnational reciprocity in small groups (usually kinship collectives), transnational exchange in circuits; and solidarity within transnational communities" (194-195). See also Sæther in this book. Johansen, Norske Skiløbere i Sydamerika, 67 .

72 Ole Hannibal Lie to father, Los Cuevas, Argentina, August 13, 1890.

73 Johansen, Norske Skiløbere i Sydamerika, 115. 
Instead he emphasizes the social differences between himself and the engineers. For instance, he describes how he travels to Chile with the engineer Rosenquist and how they, when they stop for lunch, do not eat together: "The engineers, four or five in number, ate a large dinner. I was of course also given food, though not together with them." 74 Later the engineer stayed overnight at a hotel in Los Andes, whereas Johansen ended up in jail with his belongings confiscated. He was only released upon mentioning engineer Rosenquist's name, at which point he also got his knife and his purse back. Later, with Rosenquist's assistance, he also retrieved a revolver - not the one that had been confiscated, but a bigger and better one. ${ }^{75}$ Once again these examples show that the skiers interacted with other Norwegians and that there is solidarity among them, but that at the same time it becomes clear that there are no strong networks in place that could have helped them to reorient their lives in South America when their conditions worsened. Gert Lindh, the only one of the skiers who stayed in South America, could do so not because of the other Norwegians, but because of his lasting relationships with locals.

\section{The Social Situation}

Throughout his book Johansen emphasizes the tough conditions in South America. He writes that they had met poverty and distress earlier but that what they met in Las Cuevas was worse than what they had met before: "We had seen want and misery before, but we had not seen anything like the miserable conditions we witnessed here almost every day for two or three months."76 He depicts the Italians and Frenchmen as being particularly badly dressed for the cold weather: "It's not that strange that these poor souls either froze to death or froze themselves senseless." 77

But Johansen is not always compassionate about the distress he observes. He is frequently condescending both towards South American societies and towards their inhabitants. The following quote exemplifies this attitude:

74 "Der spistes stor Middag, det vil sige Ingeniørerne som der var 4 eller 5 Stykker af. Jeg fik naturligtvis ogsaa Mad, dog ikke sammen med dem." Johansen, Norske Skiløbere $i$ Sydamerika, 86.

75 Johansen, Norske Skiløbere i Sydamerika, 92-93.

76 "Vi havde set Nød og Elendighed før; men den, som her frembød sig i en zá3 Maaneder, næsten hver Dag, havde vi ikke seet Magen til." Johansen, Norske Skiløbere i Sydamerika, 113.

77 "Det var ikke saa rart, at de stakkels Mennesker frøs i hjel eller frøs sig fordærvet." Johansen, Norske Skiløbere i Sydamerika, 114. 
First of all, there is not much civilization in South America; second of all, the South American republics are being inundated with the worst people from Europe and Asia. When you then consider that everyone from the president to the vagabond, whether native or immigrant, educated or uneducated, only has a single thought on their mind - acquiring gold no one can be surprised that the concept of "mine" and "yours" does not carry much weight. It is by no means peculiar that crude people use any means possible to obtain money without working. ${ }^{78}$

Johansen presents this is as more or less a permanent situation typical of South America. Further on in the text he has a very similar formulation:

Ever since the wars of independence, inner turmoil has disturbed the social order of the various republics and will probably do so for a long time to come. It is so easy to incite uprisings and revolutions here. Those in positions of power in the state, the city, or the province always make sure to steal, so that the disgruntled always have a legitimate grievance and a reason for chasing them out the door. When these disgruntled people then come to power, they do the same thing, so as to give the next flock of disgruntled people a chance to plunder the public treasury for a few years. ${ }^{79}$

These passages are so stereotypical that it may very well be that they have been inspired by what other authors have written about South America. However, what is striking is that Johansen immediately after the second of these rather stereotypical analyses of a socio-political situation describes a political meeting

${ }_{78}$ "For det første er Civilisationen liden i Syd Amerika; for det andet oversvømmes de sydamerikanske Republiker af de daarligste Mennesker fra Europa og Asien. Naar man saa betænker, at allesammen, fra Preæsidenten til Dagdriveren, indfødte og indvandrede, dannede og udannede, kun har én Tanke - at skaffe sig Guld; saa kan ingen forundre sig over, at Begrepet om mit og dit ikke har stort at sige. Det er intet underligt i, at raa Mennesker ved hvilkesomhelst Midler søger at skaffe sig Penge uden Arbeide." Johansen, Norske Skiløbere i Sydamerika, 119 .

79 "Indre Uroligheder har helt siden Uafhengighedskrigene oprevet de forskjellige Republikers Statssamfund og vil vel endnu i lang Tid komme til at gjøre det. Det er saa let att faa istand Oprør og Revolution her. De, som har Magten i Staten, Byen eller Provinsen passer bestandig paa at Stjæle, saa de misfornøiede atter har noget at bestride og jage dem paa Porten for. Naar saa de misfornøiede kommer til Magten, gjør de det samme, for at give den næste flok af mifornøiede Anledning til i nogle Aar at plundre Statkassen." Johansen, Norske Skiløbere i Sydamerika, 132. 
that he himself attended at the Mendoza theater. He was there with two other Norwegians, and one of the others explained to him what was being said. The political plan was to produce an uprising and overthrow the governor of the province: "A former minister of war, who had stolen two cannon batteries and five hundred of the best rifles, was the hero of the evening and spoke grandiosely." 80 But as also some loyalists attended the meeting, the situation got ugly: "During these events a scuffle broke out. ...No less than five revolver shots were fired. Then the police-soldiers moved in." ${ }^{81}$ Johansen and his friends found a backdoor and left the meeting. One person died and five were injured. ${ }^{82}$

Johansen continues to explain that whenever there is a risk of a revolution, the money loses it value, as also the banks tend to go bankrupt. He describes in other words a socio-political situation that is rather complicated and probably not very tempting for prospective migrants. In Johansen's account this sociopolitical analysis is presented in one of the final chapters, in which he also provides a rather negative description of Argentineans and how badly they treat their animals. As Argentina and its inhabitants are depicted in such a negative way, it is a chapter that clearly prepares his departure and also serves to affirm his self-image. If he did not succeed as a migrant in Argentina, it was because of Argentina, not because of him.

When he in the next chapter, the final one, describes how he leaves Argentina in January 1891 and goes to Chile, he presents the political situation with uprisings there as a surprise: "It was first then that I heard that a revolution had broken out in the whole of Chile." ${ }^{83}$ That this comes as a surprise fits very well into his account of hardships in which he himself is not responsible for what happens to him, but rather a victim of unfortunate circumstances. Likewise, he never writes directly that he was dismissed because of the argument with the engineer, but rather presents it as if he left voluntarily.8 ${ }^{84}$ Moreover, a reader who is acquainted with the political situation in Chile 1890-91 would know

8o "En forhenværende Krigsminister, der havde stjålet to Batterier kanoner og 500 af de bedste Geværer var Aftenens Helt og førde det store Ord." Johansen, Norske Skiløbere i Sydamerika, 133 .

81 "Under dette opstod der et helt Slagsmaal (...) der affyredes ikke mindre end 5 Revolverskud. Saa trængte Politisoldaterne ind" Johansen, Norske Skiløbere i Sydamerika, 133.

82 Johansen, Norske Skiløbere i Sydamerika, 133.

83 "Jeg fikk nu først høre, at der var udbrudt Revolution over hele Chili." Johansen, Norske Skiløbere i Sydamerika, 144.

84 In Aftenposten, a communication from the consul general in Buenos Aires nevertheless states very clearly that Knygg/Johansen was indeed dismissed. "De norske Skiløbere i Argentina," Aftenposten, October 15, 1891, morning edition, 2. 
that the uprisings started much earlier. Morevoer, as mentioned above, Lie writes about these uprisings already in a letter from July 26,1890 , the letter that marked the turning point in his narrative. The situation in Valparaiso that Johansen describes for January 1891 is strikingly similar to the one that Lie described already in July 1890. It thus seems that Johansen has adapted some of the historical events to fit better into his narrative.

Be that as it may, there is no doubt that the real events that took place in Chile and Argentina when the skiers were there in 1890 and 1891 did affect both the company Clark \& Co. and the skiers themselves. If it were not for the political instability in the two countries, it would presumably have been much easier for the Norwegian skiers to give South America a second chance when the company went bankrupt.

\section{The Majority Returned to Norway}

One of the skiers, Johannes M. Helland, died shortly after arrival at a hospital in Los Andes. ${ }^{85}$ Another of the company, the young sailor Hans Dags Berge, got dismissed from Clarke \& Co., whether for refusing to work on Good Friday (as Johansen states) or for drinking and scuffling (as Lie states), and as far as we know he returned to Norway. ${ }^{86}$ Only three of them remained in the Americas: Gert Lindh changed his first name to Gerardo, decided to stay in South America, and married a Chilean woman named Maria Isabel Clavel, with whom he had two daughters and two sons. ${ }^{87}$ Kristen J. Knygg moved to the United States and changed his name to Johansen. Ole Hannibal Lie also moved to the United States, before returning to Norway and marrying a Stefanie Berg, with whom he had two children in 1897 and 1899. In 1900 he took over the family farm By, which he sold already in 1904. He then remigrated to the United States and died there. ${ }^{88}$

Of the seven others, Johannes L. Haug, Kristoffer Berg, and Nikolay Sund traveled to Buenos Aires in February 1891 along with Ole Hannibal Lie, and with the consul general's assistance they (as well as Hans Fougner) received their salaries from Clark \& Co. ${ }^{89}$ with the above noted exception of Lie, they

85 Ole Hannibal Lie to brother, May 26, 1890; Johansen, Norske Skiløbere i Sydamerika, 85; Theodor Østgaard, “Vinterliv i Anderne," Aftenposten, July 15, 189o, evening edition, 2.

86 Johansen, Norske Skiløbere i Sydamerika, 74; Ole Hannibal Lie to brother, May 26, 1890.

87 Anne Heidi Røstad, e-mail message, November 21, 2013.

88 Schilbred, Gårdshistorie for Søndre Land, 244-45.

89 "De norske Skiløbere i Sydamerika. Svar fra den norske Generalkonsul," Aftenposten, August 25, 1891, morning edition, 1. 
all returned to Norway. Adolf Mosheim, Ove Løvvik, and Theodor Østgaard arrived in Buenos Aires after the others, and with the consul general's assistance they also got paid and returned to Norway. ${ }^{90}$ The last article published about the skiers in Aftenposten ends with the declaration that "none of the skiers has the slightest interest in making that trip again." ${ }^{\prime 1}$

\section{Conclusion}

In leaving their home country to do manual work, the twelve skiers discussed here are typical Norwegian migrants to Latin America. But in some other important respects the skiers differ from most of the Norwegians who went to Latin America from 1820 to 1940 . They were for example probably both the first and the last Norwegians to be hired to work in South America for their skiing skills. More importantly, they were contracted in Norway, the company paid for their passage, and they left as a group. Migrants would usually not have a work contract until after arrival, and they would either pay for their tickets themselves or work their way over the Atlantic. In spite of these special circumstances, this case is a prime one for studying the motives and motivations that Norwegian migrants might have had for going to Latin America and for either staying or not staying there, not least because the case is extremely well documented. Many sources depict this event, so that although this story almost sounds too good to be true, there is no doubt that the twelve men actually existed, that they left Norway in January 1890 , and that they were employed as skiers by Clark \& Co. in Argentina and Chile in 1890-91.

In this chapter I have examined in particular what three of these skiers wrote about their stay in Argentina and Chile, attempting to find out why the skiers left Norway for Argentina and why so few of them decided to stay once they had arrived. The prospect of being able to make good money seems to have played an important role in their decision to go to Argentina, but they also seem to have been attracted by the adventurous aspects related to going off the beaten track. Nothing in what they write suggests that they had any particular personal reasons for going to Latin America. Clark \& Co.'s advertisement seems to have been of decisive importance, and its publication in Norway and the consul general's subsequent defense of it demonstrate that there were some active Argentinean-Norwegian relations that allowed for this to happen.

$90 \quad$ "De norske Skiløbere i Argentina," Aftenposten, October 15, 1891, morning edition, 2.

91 "Ingen af Skiløberne har den mindste Lyst til at gjøre den Tur om igjen." "De norske Skiløbere i Argentina," Aftenposten, October 15, 1891, morning edition, 2. 
The narratives studied here also reveal that several Norwegians already worked for Clark \& Co. in the Andes, such as the engineers in Las Cuevas and a clerk who worked at the office in Mendoza. These Argentinean-Norwegian relations may have opened up for the skiers' positions being created, but they do not seem to have been dense enough to make it possible for the skiers to re-establish themselves professionally when they lost their positions at Clark \& Co. This probably contributed to the skiers' decision not to stay. There were not many Norwegians in the Andes, and from what they write, the skiers did not seem to interact well with the locals or with other migrants. The exception is Lindh, who shortly after the group's arrival met a Chilean woman whom he later married.

The social conditions probably also played a decisive role in the decision not to stay. A revolution had broken out in Chile, the political situation in Argentina was also very unstable, and the company they worked for went bankrupt. Both Johansen and Lie write about these political and economic events and about how they affect their situation. The lack of a Norwegian network and the unstable situation made it difficult for the skiers to make money. And as making money was their main motive for going to South America in the first place, it is not strange that most of them decided to go back or to move on to the United States. 